\title{
Development of Cheerful Interactive Multimedia on the Content of Class 5 Social Studies Materials in Elementary Schools
}

\author{
Rossy Pratiwi ${ }^{1 *}$, Anak Agung Gede Agung ${ }^{1}$ \\ ${ }^{1}$ Universitas Pendidikan Ganesha, Indonesia \\ "Corresponding author. Email: rossypratiwi911@ gmail.com
}

\begin{abstract}
This research was developed based on the results of an analysis of the needs of learning media in elementary schools, because the lack of varied learning media and limited learning resources. Therefore, this research aims to (1) describe the design process of a cheerful interactive multimedia product with a content of natural appearance and the diversity of Indonesian flora and fauna, (2) determine the results of cheerful interactive multimedia validation according to the results of expert reviews, trials. The development model used as a reference in this research is ADDIE (Analyze, Design, Development, Implementation, and Evaluation). This research using data collection methods in the form of a questionnaire. The data analysis techniques used in this research are qualitative analysis and quantitative analysis. The results of data analysis were obtained as follows: (a) the results of the assessment of the subject matter content experts obtained a percentage of 92.50 with a very good category, (b) the results of the assessment of the instructional design experts obtained a percentage of 92.31 in the very good category, (c) the results of the assessment of the instructional media experts obtained a percentage result of 92.64 in the very good category. (d) the results of the product assessment from individual tests obtained 94.20 in the very good category. Based on the results of validation from experts as well as individual tests, it can be decided that interactive multimedia cheerful for material content of natural appearance and diversity of Indonesian flora and fauna is suitable for use in the learning process in grade 5 elementary school. For the supporting tools and materials needed in the application of this media, it is necessary to have CDs, computers / laptops and cellphones.
\end{abstract}

Keywords: Cheerful Interactive Multimedia, Social Studies, ADDIE

\section{INTRODUCTION}

A good education is an education which able to create fun learning circumstances by making it easier for students to understand the material of the learning process with the result that it becomes more efficient [1]. Education is the most important thing because through education human able to change their life to be better from any aspect.

According to [2] education is a long process that is continuously done by human, with different problems along with the development of time and technology [3] Education is very important to improve the quality of human resources, so that is why education should have good quality. Along with the improvement [4] the quality of education will be able to improve the level of education.
In achieving good quality education, it is necessary to have media of learning that may support the delivered material in the learning process. Learning media can be defines as a tool that is used to mediating the teachers and the students to learn a material [5]. Learning media can help in the process of teacher and student approaches to make the learning situation more meaningful. If learning media is used properly, the presented material will give students impressions and experiences about wide knowledge and can achieve the purpose of learning. [6] states that learning media can be defined as a physical or non-physical tool that is deliberately used as a mediator between teacher and student in understanding material of learning so it will more effective and efficient.

The benefits of media in the learning process are to facilitating interaction between teacher and student so that the learning activities will be more effective and 
efficient [7]. The main element of the success in using learning media is the achievement of learning purposes. Learning media has three variations, namely audio, visual and audio-visual media. Along with time, learning media is made as attractive as possible to attract student's interest in learning. In broader terms, Yusufhadi Miarso defines learning media as anything that can be used to stimulate students thoughts, feelings, attention, and willingness to encouraging the learning process of a student [8].

In the media, it is made contains a combination of text, images, video, and audio which is presented in the learning or also known as multimedia. [9] revealed that multimedia is a combination of several different media (text, sound, video, and images) to produce multimedia products (audio, films, games). Multimedia which is usually used in the learning process is commonly interactive. [10] revealed that multimedia is a combination of various media (text, images, video, and sound) combined with the use of certain software to facilitate interactive communication [11]

Interactive multimedia is a combination of various media, such as text, audio, graphics, animation, and video that can be used to convey information or messages that are completed with control devices and can be operated by the user. Interactive multimedia is a combination of various media packaged with digital media which is used to convey messages from teacher to student with a combination of text, audio, graphics, animation, and video. Along with interactive multimedia contains discussion of the material, learning videos, and evaluation questions about the related material and the existence of an interaction between teacher and student during the learning process. In interactive multimedia, learning materials are presented or packaged attractively by combining aspects such as animation, sound, images, text, and video. Explains that multimedia is a combination of text, graphics, animation, sound, and video combined into one under computer control as an encouragement used to display information, messages, or learning content. So, fun interactive multimedia is a medium that is packaged as attractive as possible to convey the teacher's message to students in learning to create a pleasant learning situation. Also, the benefits of multimedia can be used as independent learning material according to (Eka, 2013).

Based on the results of observation and survey at SDN 5 Pedungan, there were problems in the learning material content of the natural appearance and the diversity of Indonesian flora and fauna by grade 5 students, namely limited learning resources and less varied learning media. So that students become passive during the learning process. This is also experienced by [12] in their research which suggests that student involvement in the learning process is less involved, students only act as listeners and observers during the learning process. This is due to the lack of developing interactive media in the learning process. The same thing was experienced by [13] namely the learning media used in SD Negeri 2 Seririt is very limited, the learning method used is by lecturing, which caused student activity in the learning process to decrease and they get bored easily, therefore, the students experienced an impairment in learning outcomes. The learning process will be more fun with interactive multimedia because through this media students can think critically and can collaborate on games with learning. In general, students feel more meaningful and interesting learning with games in the learning process. Students will be able to operate game applications, especially those on computers, laptops, or cellphones, this implementation can be done at home or school [14].

Educational games are needed for elementary schools because they are following the characteristics of students possessed by elementary school students. According to [12] explains the various benefits obtained from educational games including, as a means of getting to know each other, appreciating, practicing to develop one's abilities, forging feelings, and being able to recognize the strengths of oneself and friends.

According to [15] Social Science is a subject matter that contains various social phenomena that exist in the community. [16] which states that social science is a learning material available in social life such as sociology, geography, history, economics, political science, and anthropology which presents daily problems in the surrounding environment.

The main objective of Social Sciences according to [17] states that IPS is an education that aims to prepare students' social life for changes in social aspect in the country and globally. Along with the opinion [18] namely to develop the potential in students to be able to adapt, have a positive attitude, be sensitive to social problems, and be able to solve problems that occur. The statement was also expressed by

Based on the descriptions that have been described, the first preliminary study carried out is conducting observations and interviews with the teacher of fifth grade of SDN 5 Pedungan to determine the needs of analysis, analysis of student characteristics, and analysis of the school environment. The results of observations and interviews in the place obtained data, namely (1) the learning resource used by students, namely the BOS book, (2) the method used was lecturing, (3) the media used in the learning process were concrete media, blackboards, and videos, (4) facilities owned, namely LCD, computer, wifi. From the problems that occur in the place, the researcher provide solutions by developing cheerful interactive multimedia products on the material content of natural appearance and the diversity of Indonesian flora and fauna in fifth grade of SDN 5 Pedungan which can be used as alternative and 
innovative learning media so that students can learn optimally.

\section{METHODS}

The research used is a research design and development refers to the ADDIE research method (Analyze, Design, Development, Implementation, and Evaluation) [19]. The implementation of product validation by experts was held on December 29, 2020, by learning design experts and learning media experts, and on January 11, 2020, by subject matter content experts.

The data collection technique used in this study was a questionnaire. The questionnaire method is a way of obtaining or collecting data by sending a list of questions/statements to respondents/research subjects
[20]. The questionnaire method is used when testing products on test subjects, namely subject matter content experts, learning media experts, instructional design expert, and individual trials consisting of three fifth grade students who have different levels of learning achievement, which are 1 high achieving student, 1 medium achieving student, and 1 low achieving student. The instrument used in data collection in this study was a questionnaire.

This research can only be done until the feasibility test or product validation, this is because the situation and conditions are less supportive, that is Covid-19. The grid of research instruments from subject matter content experts, instructional design experts, instructional media experts, and student responses, is as follows.

Table 1. Lattice Instrument - Lesson Content Expert Grid

\begin{tabular}{|c|c|c|c|c|}
\hline No. & Aspects & Indicators Indicators & $\begin{array}{c}\text { No. } \\
\text { Indicators }\end{array}$ & $\begin{array}{l}\text { Number of } \\
\text { Items }\end{array}$ \\
\hline 1. & Material & $\begin{array}{l}\text { a. Material conformity with } \mathrm{KI}, \mathrm{KD} \text {, Indicators and } \\
\text { Learning Objectives }\end{array}$ & 1 & 1 \\
\hline 2. & Kebahasaan & $\begin{array}{l}\text { a. Conformity of material with competence b. } \\
\text { b. Clarity of material description } \\
\text { c. Ease of understanding the material } \\
\text { d. Material suitability with real-life students }\end{array}$ & $2,3,4,5$ & 4 \\
\hline 3. & Evaluation & a. Conformity between images and materials & 6 & 1 \\
\hline 4. & Language & $\begin{array}{l}\text { a. Conformity with Indonesian rules of text readability } \\
\text { b. Conformity with the development of the age of } \\
\text { learners }\end{array}$ & $7,8,9$ & 3 \\
\hline 5. & Evaluation & a. Conformity of evaluation with materials & 10 & 1 \\
\hline \multicolumn{4}{|c|}{ Amount } & 10 \\
\hline
\end{tabular}

Table 2. Lattice Instrument - Instructional Design Expert Grid

\begin{tabular}{|c|c|c|c|c|}
\hline No. & Aspects & Indicators & $\begin{array}{l}\text { No. } \\
\text { Instruments }\end{array}$ & $\begin{array}{l}\text { Number of } \\
\text { Items }\end{array}$ \\
\hline 1. & Visualisasi & $\begin{array}{l}\text { a. Media display } \\
\text { b. Image clarity }\end{array}$ & 1,2 & 2 \\
\hline 2. & Curriculum & $\begin{array}{l}\text { a. Alignment of learning objectives with media } \\
\text { b. Alignment of learning objectives with materials } \\
\text { c. Learning steps }\end{array}$ & $3,4,5$ & 3 \\
\hline 3. & Motivation & a. Motivational giving & 6 & 1 \\
\hline 4. & Serving & $\begin{array}{ll}\text { a. } & \text { Clarity of material description } \\
\text { b. } & \text { Accuracy of presentation of illustration images }\end{array}$ & 7,8 & 2 \\
\hline 5. & Material & $\begin{array}{l}\text { a. The attractiveness of the delivery of materials } \\
\text { b. Presentation of material conformity with the } \\
\text { character of students }\end{array}$ & $9,10,11$ & 3 \\
\hline 6. & Text & a. Text clarity & 12 & 1 \\
\hline 7. & Evaluation & a. Compatibility of the problem with indicators & 13 & 1 \\
\hline \multicolumn{4}{|c|}{ Amount } & 13 \\
\hline
\end{tabular}

Table 3. Lattice Instrument - Learning Media Expert Grid

\begin{tabular}{|c|l|l|c|c|}
\hline No. & \multicolumn{1}{|c|}{ Aspects } & \multicolumn{1}{|c|}{ Indicators } & $\begin{array}{c}\text { No. } \\
\text { Instruments }\end{array}$ & $\begin{array}{c}\text { Number of } \\
\text { Items }\end{array}$ \\
\hline 1. & Display & $\begin{array}{l}\text { a. Attractive product display } \\
\text { b. Conformity of design with student characteristics }\end{array}$ & 1,2 & 2 \\
\hline 2. & Text & a. Text readability font size conformity & 3,4 & 2 \\
\hline 3. & Pictures & $\begin{array}{l}\text { a. Image fit } \\
\text { b. Image clarity } \\
\text { c. Image layout }\end{array}$ & $5,6,7$ & 3 \\
\hline 4. & $\begin{array}{l}\text { Optimization } \\
\text { Technical }\end{array}$ & b. Ease of navigation buttons & $8,9,10$ & 3 \\
\hline
\end{tabular}




\begin{tabular}{|c|l|l|c|c|}
\hline No. & \multicolumn{1}{|c|}{ Aspects } & \multicolumn{1}{c|}{ Indicators } & $\begin{array}{c}\text { No. } \\
\text { Instruments }\end{array}$ & $\begin{array}{c}\text { Number of } \\
\text { Items }\end{array}$ \\
\hline 5. & Color & $\begin{array}{l}\text { a. Background color conformity } \\
\text { b. Image color conformity } \\
\text { c. Font color conformity }\end{array}$ & $11,12,13$ & 3 \\
\hline 6. & Animation & $\begin{array}{l}\text { a. Animation quality Of } \\
\text { b. Animation Attractiveness } \\
\text { c. According to the student character }\end{array}$ & $14,15,16$ & 3 \\
\hline 7. & Audio & a. Audio clarity & & 17 \\
\hline \multicolumn{1}{c|}{ Amount } & & 1 \\
\hline
\end{tabular}

Table 4. Grid Instrument - Individual Trial Grid

\begin{tabular}{|c|c|c|c|c|}
\hline No. & Aspects & Indicators & $\begin{array}{c}\text { No. } \\
\text { Instruments }\end{array}$ & $\begin{array}{l}\text { Number of } \\
\text { Items }\end{array}$ \\
\hline 1. & Visualization & a. The attractiveness of the display of learning media & 1 & 1 \\
\hline 2. & $\begin{array}{l}\text { Presentation } \\
\text { of Materials }\end{array}$ & $\begin{array}{l}\text { a. Ease of understanding material } \\
\text { b. Clarity of material description } \\
\text { c. Material balance with evaluation }\end{array}$ & $2,3,4$ & 3 \\
\hline 3. & Text & $\begin{array}{ll}\text { a. } & \text { Quality of text used } \\
\text { b. } & \text { Clarity of text used }\end{array}$ & 5,6 & 2 \\
\hline 4. & Pictures & $\begin{array}{l}\text { a. Image quality used } \\
\text { b. Obscurity and images used }\end{array}$ & 7,8 & 2 \\
\hline 5. & Motivation & a. Provide the spirit / motivation of learning & 9 & 1 \\
\hline 6. & Evaluation & a. The suitability of the question with the question & 10 & 1 \\
\hline \multicolumn{4}{|c|}{ Amount } & 10 \\
\hline
\end{tabular}

To provide meaning or categories from the results of expert assessments and individual trials, it is translated using a Likert scale, which is as follows.

Table 5. Skala Likert

\begin{tabular}{|c|c|}
\hline Score & Description \\
\hline 4 & Strongly Agree \\
\hline 3 & Agree \\
\hline 2 & Disagree \\
\hline 1 & Strongly Disagree \\
\hline
\end{tabular}

Source: [21]

\section{DISCUSSION}

To knowing the validity of a product, it requires validation assessment from experts, the assessment is value based on several aspects related to the product that is developed and also obtaining criticism and suggestions from the validator so that the product being developed will receive revisions to perfecting the developed product. The following is the result of validation from subject matter content experts, instructional design experts, instructional media experts, and individual trials.
Table 6. Percentage of Validity Results of Cheerful Interactive Multimedia Development

\begin{tabular}{|c|l|c|c|}
\hline $\begin{array}{c}\mathbf{N} \\
0\end{array}$ & Test Subjects & $\begin{array}{c}\text { Validity } \\
\text { Result (\%) }\end{array}$ & Description \\
\hline 1. & $\begin{array}{l}\text { Expert Test } \\
\text { Subject Matter }\end{array}$ & 92.50 & Excellent \\
\hline 2. & $\begin{array}{l}\text { Instructional } \\
\text { Design Expert } \\
\text { Test }\end{array}$ & 92.30 & Excellent \\
\hline 3. & $\begin{array}{l}\text { Learning } \\
\text { Media Expert } \\
\text { Test }\end{array}$ & 92.64 & Excellent \\
\hline 4. & $\begin{array}{l}\text { Individual } \\
\text { Trials }\end{array}$ & 94.20 & Excellent \\
\hline
\end{tabular}

To provide meaning or category from the results of the expert's assessment and individual trials, it is using a scale of 5 as the translation, which is as follows.

Table 7. Scale 5 Achievement Rate Conversion

\begin{tabular}{|c|l|l|l|}
\hline $\begin{array}{c}\text { N } \\
0\end{array}$ & $\begin{array}{c}\text { Achievement } \\
\text { Rate (\%) }\end{array}$ & \multicolumn{1}{|c|}{ Category } & \multicolumn{1}{|c|}{ Description } \\
\hline 1. & $90-100$ & Excellent & $\begin{array}{l}\text { No Revision } \\
\text { Required }\end{array}$ \\
\hline 2. & $75-89$ & Good & Minor Revisions \\
\hline 3. & $65-74$ & $\begin{array}{l}\text { Good } \\
\text { Enough }\end{array}$ & $\begin{array}{l}\text { Revised to } \\
\text { Taste }\end{array}$ \\
\hline 4. & $55-64$ & Less Good & $\begin{array}{l}\text { Many Things } \\
\text { Revised }\end{array}$ \\
\hline 5. & $0-54$ & Very Poor & $\begin{array}{l}\text { Repeated } \\
\text { Making Products }\end{array}$ \\
\hline
\end{tabular}

Source: [22]

From the valuation of the results by the expert subject content for fun interactive multimedia with the content of the material appearance of nature and the diversity of 
Indonesian flora and fauna fifth-grade students in SDN 5 Pedungan obtained a total score of 37 with a percentage of 92.50 (very good). with the material content of natural appearance and diversity of Indonesian flora and fauna fifth-grade students of SDN 5 Pedungan obtained a total score of 48 with a percentage of 92.30 (very good), and expert valuation of instructional media for fun interactive multimedia with the subject of natural appearance and diversity of Indonesian flora and fauna fifth grade of SDN 5 Pedungan obtained a score of 63 with a percentage of 92.64 (very good) as well. As the results of individual test assessments for fun interactive multimedia with the subject of natural appearance and diversity of Indonesian flora and fauna, the fifth grade of SDN 5 Pedungan received a score of 113 with a percentage of 94.20 (very good). Based on the results of the validation assessment of each expert, the media products developed in the learning process of natural appearance and the diversity of Indonesian flora and fauna are clear, interesting, and exactly on target.

In the validation process, the validator provides some suggestions for improving the product that is developed, while the suggestions given by the validator are as follows.

a. In describing the material, explaining the concepts, facts, principles, procedures, and generalizations regarding the Indonesian flora and fauna

b. The replacement options are placed in the same location

c. Additional suitable images and sources

d. Adding learning objectives

The results of fun interactive multimedia products that have been developed are as follows.

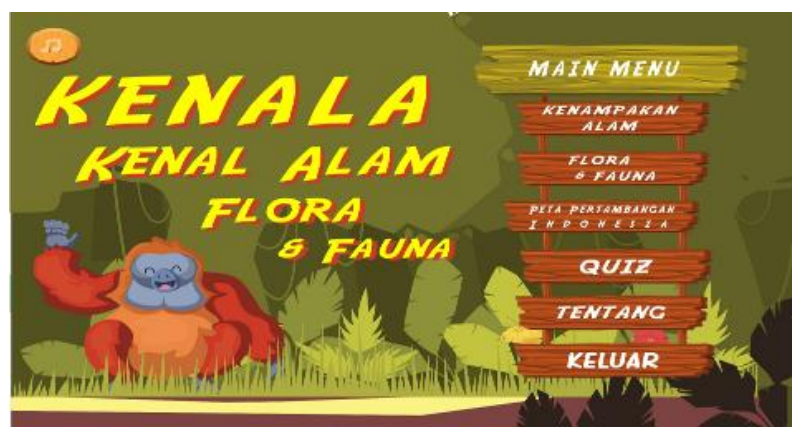

Figure 1. Menu on the Kelana Application
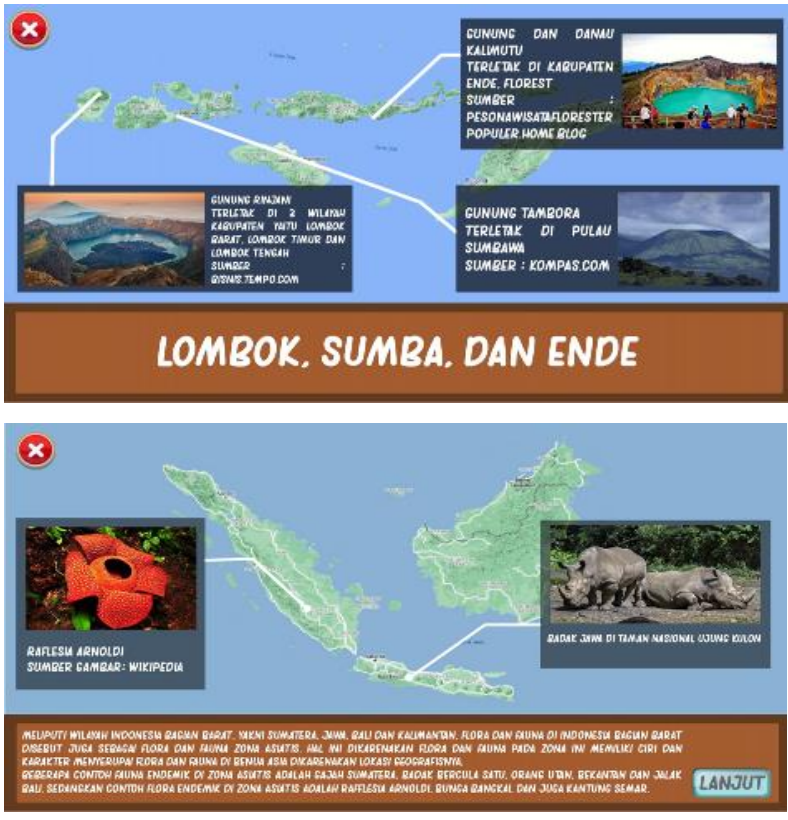

Figure 2. Material on the Kelana Application

After validated with the validator, for the next step the researcher used interactive multimedia fun learning for individual tests consists of 1 high achieving student, 1 medium achieving student, and 1 low achieving student from grade 5 SDN 5 Pedungan. This has to be done to determine the validation and feasibility of the product if it is used on the subject of natural appearance and the diversity of Indonesian flora and fauna.

The step in making this product use the ADDIE development model, this model consists of the first stage, namely the needs analysis stage, student characteristics, and the school environment to find out the learning resources used by students, the facilities owned by the school, and the characteristics of the students. As stated by [23], this analysis aims to find out the basic problems in interactive media development. The problems found at this stage are limited learning resources, less varied learning media, but the facilities owned by the school are already supportive.

The second stage is the design stage, at this step designing the storyboard, flowchart, lesson plans, and designing using the Adobe Animate software. This design step combining text, audio, animation following the material used to design the product that being developed. The design of this media is made by the character of the students both in terms of color, animation, readability of writing, or the content of the learning material.

The third stage, namely the implementation of the development stage, provides products to three students in fifth-grade students at SDN 5 Pedungan consisting of one high, medium, and low achievement student to determine the feasibility of the developed product. 
The fourth stage is implementation, at this stage, a school must prepare supporting facilities and infrastructure to be able to support the operation of this product in the learning process. As for the infrastructure needed, such as CDs, laptops/computers, and phones.

The last stage is evaluation, at this stage using a formative evaluation. Formative evaluation is an evaluation that is done at each stage which is used to minimize the error rate or product shortage from each response. According to [24] states that formative evaluation can be defined as the process of providing information to be used as a basis for making decisions to improve product quality. The same with [25] states that formative evaluation functions to improve a product in the development process or has not been completed. Therefore, this study uses formative evaluation to improve the product from each stage through expert reviews.

Overall, it can be concluded that interactive multimedia is fun to the subject of natural appearance and diversity of Indonesian flora and fauna in fifth-grade students at SDN 5 Pedungan. This is in line with the research conducted by [26] in the title Pengembangan Multimedia Interaktif IPA with guided inquiry-oriented research on human respiratory system material for fifthgrade students of SDN 3 Kebonsari Malang, which concluded that the developed product achieved as a product with valid assessment, attractive and practical category, so that the product is declared worth to use by fifth-grade students of SDN Kebonsari 3 Malang, the statement is the same as the research conducted by [27] in the title Pengembangan Multimedia Interaktif Untuk Pembelajaran Bicara Bagi Siswa Kelas IV Sekolah Dasar concluded that the developed product is suitable to use by fifth-grade students of Elementary School.

\section{CONCLUSION}

The results of data analysis were obtained as follows (a) the results of the assessment of the subject matter content experts obtained a percentage of 92.50 in the very good category, (b) the results of the assessment of the instructional design experts obtained the percentage of 92.31 in the very good category, (c) the results of the assessment of the instructional media experts obtained a percentage result of 92.64 with a very good category. (d) the results of the product assessment from individual tests obtained 94.20 in the very good category. Based on the results of validation from experts as well as individual tests, it can be decided that the interactive multimedia is fun for the material content of natural appearance and the diversity of Indonesian flora and fauna suitable for use in the learning process in fifth grade of SDN 5 Pedungan.

\section{REFERENCES}

[1] I. B. K. J. Ardika, K. Pudjawan, I. D. K. Tastra, Pengembangan Multimedia Interaktif Pada Pembelajaran PKN di SMP Negeri 1 Banjar, Jurnal Edutech Undiksha, vol. 3(1), 2015. DOI: https://doi.org/http://dx.doi.org/10.23887/jeu.v3i1. 5703

[2] D. Fatimah, Pengembangan Media Katela untuk Operasi Hitung Perkalian Pada Siswa 2 Sekolah Dasar, Jurnal Penelitian dan Pengembangan Pendidikan 4(3) (2020) 526-532. Retrieved from https://ejournal.undiksha.ac.id/index.php/JJL/articl e/view/29741

[3] D. C. Rahayuningrum, Hubungan Motivasi Bermain Game Online Dengan Adiksi Game Online Pada Remaja, Jurnal Kesehatan Medika Saintika, 8(1) (2017) 9-16. DOI: https://doi.org/http://dx.doi.org/10.30633/8812201 720179-161

[4] A. Mukhid, Meningkatkan kualitas pendidikan melalui sistem pembelajaran yang tepat, TADRIS: Jurnal Pendidikan Islam, vol. 2(1), 2007. DOI: https://doi.org/http://dx.doi.org/10.19105/tjpi.v2i1. 211

[5] N. M. M. Y. Pradesa, I. N. Jampel, I. I. W. Suwatra, Pengembangan Multimedia Pembelajaran Interaktif Berbasis Flash Mata Pelajaran PKn Kelas VI SD, Jurnal Edutech Undiksha, vol. 2(1), 2014. DOI: https://doi.org/http://dx.doi.org/10.23887/jeu.v2i1. 3641

[6] Musfiqon, Pengembangan Media Belajar dan Sumber Belajar, Jakarta: Prestasi Pustakakarya, 2012.

[7] D. M. A. A. Nida, D. P. Parmiti, A. I. W. I. Y. Sukmana, Pengembangan Media Kartu Bergambar Berorientasi Pendidikan Karakter Pada Mata Pelajaran Bahasa Bali, Jurnal Edutech Undiksha 8(1) (2020) 16-31. DOI: https://doi.org/http://dx.doi.org/10.23887/jeu.v8i1. 25393

[8] S. G. Pravitasari, M. L. Yulianto, Penggunaan Multimedia Interaktif Dalam Pembelajaran Bahasa Inggris (Studi Kasus di SDN 3 Tarubasan Klaten), Profesi Pendidikan Dasar 1(1) (2018) 37. DOI: https://doi.org/10.23917/ppd.v1i1.3825

[9] I. G. H. Prastya, K. Pudjawan, I. K. Suartama, Pengembangan Multimedia Pembelajaran Interaktif Mata Pelajaran Bahasa Indonesia dengan Model ADDIE Untuk Siswa Kelas VII Semester Genap Tahun Pelajaran 2014-2015 di SMP Negeri 1 Banjar, Jurnal Edutech Undiksha, vol. 3(1), 2015. DOI: 
https://doi.org/http://dx.doi.org/10.23887/jeu.v3i1. 5609

[10] Munir, Multimedia Konsep dan Aplikasi dalam Pendidikan, Bandung: Alfabeta, 2012.

[11] H. Hotimah, A. Muhtadi, Pengembangan multimedia pembelajaran interaktif IPA untuk meningkatkan pemahaman siswa pada materi Mikroorganisme SMP, Jurnal Inovasi Teknologi Pendidikan 4(2) (2018) 201-213. DOI: https://doi.org/10.21831/jitp.v4i2.15047

[12] I. S. Hernaningtyas, R. E. Susetyarini, R. Widodo, Pengembangan Multimedia Interaktif Ceria (MIC) Pembelajaran Tematik Di Sekolah Dasar, Jurnal Pemikiran dan Pengembangan Sekolah Dasar (JP2SD) 1(4) (2016) 256. DOI: https://doi.org/10.22219/jp2sd.vol1.no4.256-266

[13] F. A. Bakhtiar, Pengembangan Aplikasi Berbasis Multimedia pada Pembelajaran Tematik Kelas III Sekolah Dasar, Mimbar Sekolah Dasar 5(1) (2013) 16. DOI: https://doi.org/10.17509/mimbarsd.v5i1.9363

[14] V. A. Erwin, Y. Syukur, Multimedia Interaktif Bermuatan Permainan Edukatif di Sekolah Dasar, Jurnal Basicedu 3(3) (2019) 901-908. DOI: https://doi.org/https://doi.org/10.31004/basicedu.v3 i3.183

[15] N. W. D. Endrayanti, Pengembangan Multimedia Pembelajaran Interaktif Dengan Model 4-D Pada Mata Pelajaran IPS Terpadu, E-Journal Edutech, vol. 2(1), 2014. DOI: https://doi.org/http://dx.doi.org/10.23887/jeu.v2i1. 3598

[16] D. A. Setiawan, W. Wahjoedi, S. M. Towaf, Multimedia Interaktif Buku Digital 3D Pada Materi IPS Kelas IV Sekolah Dasar, Jurnal Pendidikan: Teori, Penelitian, dan Pengembangan 3(9) (2018) 1133-1141.

[17] A. M. Fanny, S. P. Suardiman, Pengembangan multimedia interaktif untuk mata pelajaran ilmu pengetahuan sosial (IPS) sekolah dasar kelas V, Jurnal Prima Edukasia 1(1) (2013) 1-9. DOI: https://doi.org/https://doi.org/10.21831/jpe.v1i1.23 11

[18] N. Wahyuningtyas, F. A. D. Rosita, Pengembangan Multimedia Interaktif Berbasis Android Pada Materi Kehidupan Sosial Masyarakat Indonesia, Sejarah dan Budaya: Jurnal Sejarah, Budaya, dan Pengajarannya 13(1) (2019) 34-41. DOI: https://doi.org/http://dx.doi.org/10.17977/um020v1 3i12019p34
[19] I. M. Tegeh, Metode penelitian pengembangan pendidikan, Singaraja: Universitas Pendidikan Ganesha, 2010.

[20] A. A. G. Agung, Metodelogi Penelitian Pendidikan, Singaraja: FIP Undiksha, 2014.

[21] Sugiyono, Metode Penelitian Pendidikan Pendekatan Kuantitatif, Kualitatif dan R\&D, Bandung: Alfabeta, 2019.

[22] I. M. Tegeh, I. M. Kirna, Metode penelitian pengembangan pendidikan, Singaraja: Universitas Pendidikan Ganesha, 2010.

[23] K. H. Y. W. Geni, I. K. Sudarma, L. P. P. Mahadewi, Pengembangan Multimedia Pembelajaran Interaktif Berpendekatan Contexstual Teaching and Learning (CTL) Pada Pembelajaran Tematik Siswa Kelas IV di SD Negeri 1 Paket Agung, Jurnal Edutech Undiksha 8(2) (2020) 1-16.

[24] I. Agung, Mengembangkan Profesionalitas Guru (Upaya Meningkatkan Kompetensi dan Profesionalisme Kinerja Guru), Jakarta: Bee Media Pustaka, 2014.

[25] I. W. Budiarta, Pengembangan Multimedia Interaktif Model ADDIE Untuk Meningkatkan Motivasi Belajar Sejarah Kelas X-1 Semester Genap Di SMAN 1 Sukasada, Buleleng, Bali, Jurnal Pendidikan Sejarah, vol. 4, 2016. DOI: https://doi.org/http://dx.doi.org/10.23887/jjps.v4i2. 3620

[26] T. N. Akbar, Pengembangan multimedia interaktif IPA berorientasi guided inquiry pada materi sistem pernapasan manusia kelas V SDN Kebonsari 3 Malang, Jurnal Pendidikan: Teori, Penelitian, dan Pengembangan, 1(6) (2016) 1120-1126. DOI: https://doi.org/http://dx.doi.org/10.17977/jp.v1i6.6 456

[27] F. Y. Rosita, Pengembangan Multimedia Interaktif Untuk Pembelajaran Berbicara Bagi Siswa Kelas IV Sekolah Dasar, JINoP (Jurnal Inovasi Pembelajaran) 1(1) (2015) 25. DOI: https://doi.org/10.22219/jinop.v1i1.2445 